\title{
Early Childhood from a Developmental Perspective and Counseling Services
}

\author{
Yarmis Syukur \\ Guidance and Counseling Department \\ Universitas Negeri Padang \\ Padang, Indonesia \\ yarmissyukur@yahoo.co.id
}

\begin{abstract}
This article discusses the development of early childhood with the peculiarities that distinguish it from development in other life spans. Early childhood there are obstacles in its development so that disrupt the activities that followed. Conversely, there is an early childhood that shows the ability to match the progress being passed. Barriers in development may indicate a lack of success in achieving the development task. It is therefore important to recognize how early childhood development of psychological aspects and what to do in case of obstacles and problems because the problem of early childhood is not an issue of early childhood alone, but can interfere with the continuity of activities followed by these early children and families. For young children who have difficulty can be assisted with special treatment for overcome. Abandonment of early childhood development, can affect the achievement of learning and development of early childhood itself. Therefore, educators need to know and understand how the development of early childhood and how also the recommended attitude in order to happen optimization of development.
\end{abstract}

Keywords—early childhood; development; counseling services

\section{INTRODUCTION}

General opinions about early childhood are children aged 0-6 years. They usually attend preschool programs or kindergarten. In Indonesia, early childhood participates in child care programs and there is also a play group. Early childhood education is a coaching effort aimed at children from birth up to the age of six through education provision to assist physical and spiritual growth and development in order for the child to have readiness in entering further education [1].

Early childhood is also called the golden age, where the brain growth of children is very rapid because of the creation of billions of brain cells [2]. Therefore, early childhood needs to get attention from various parties. Moreover, the early age in the human life span is shown in the lives of individuals who are relatively powerless and dependent on others. Early childhood is categorized by experts as a childhood with two different periods, namely early childhood and late childhood. Early childhood from the age of two years until the age of six years and the end of childhood from the age of six years until the child matures sexually [3]. Having an early child is a fun life for parents and family. Early childhood can bring happiness because of the many cuteness and uniqueness they display. Families who have early childhood, life and family atmosphere is more crowded and more dynamic than families who do not have children early childhood. Biologically, the existence of early childhood in the family is a picture that the family is a productive family so that the Caliphate on earth can be continued. Psychologically, early childhood provides a sense of happiness and pride for parents and family because it can continue the descendants and heirs of family wealth. Even from a religious standpoint, having an early child can help parents in their old age even after death.

\section{LITERATURE REVIEW AND DISCUSS}

\section{A. How are early childhood from a developmental perspective?}

Early childhood from the perspective of development cannot be separated from the nature of the development in question. Development, in general, is a change that concerns the psychological aspects of the individual. Progress means a series of progressive changes that occur as a result of the process of maturity and experience [3]. While Van den Daile mentions development as a qualitative change [3]. Early childhood development shows characteristics that distinguish it from progression in later periods. Some parents call early age with inviting problems (difficult age), because early childhood is often angry for no reason, does not want to be helped and tend to reject the expression of affection. Conditions are so different from the baby's age that tend to be sweet and not much whim. The National Association for the Education of Young Children presents the following: (1) having a great curiosity, (2) being a unique person, (3) liking to fantasize and imagining, (4) the most potential time for learning, (5) showing egocentric attitudes, (6) having short concentration power spans, and (7) as part of social beings [4]. This means that early childhood has a developmental task as there are also at other stages of development.

Early childhood development tasks exist that refer to the developmental tasks of the infant and others who sort them out in the early developmental tasks of childhood. Nevertheless, each individual can guide his or her developmental tasks whether achieving tasks that should be controlled or not. Some of the early childhood activities are interesting to note so that they can serve as a basis for providing educational services to them such as how they walk, raise their hands / feet and run individually, walk and run together, walk, run in various ways (more than two), jumping in different directions individually, jumping in different directions together with friends, running 
combination moves, running, jumping individually, auxiliary body movements, performing fantasy movements by story, performing body movements based on the lyrics song [5].

According to Carolyn Triyon and J.W.Lilienthal the tasks that must be mastered every individual development is; (3) learning to get along with other children, (4) developing selfcontrol, (5) learning the various roles of people in society, (6) learning to know the body of each, (7) learning to master fine motor skills and rough, (8) learning to know the physical environment and controlling, (9) learning to master new words to understand the child / others, (10) developing positive feelings in dealing with the environment [6]. Task of development of childhood 0-5 years old, namely; (2) learning to distinguish between the sexes, (3) achieving physical maturity, (4) forming simple concepts of physical social reality, (5) learning to connect emotionally with parents, siblings, and others (6) learning to understand good and bad [7]. While the task of age development of children (6-11 years) is; (1) learning the physical skills necessary for simple games, (2) building a healthy lifestyle, for oneself and the environment, (3) learning to get along with peers, (4) learning to play a proper social role according to gender, (5) learning basic skills; reading, writing and arithmetic, (6) developing the necessary concepts in everyday life, (7) developing conscience, morals and values, (8) achieving personal freedom, (9) developing attitudes toward groups social and social institutions [7].

Considering the above opinion it can be concluded that early childhood is a child who in its development shows the uniqueness, like fantasize and the most potential for learning, demands the mastering of a number of skills in practice such as learning to control the disposal of sewage. Besides, it also produces skills related to the mastery of knowledge and understanding such as success in learning the difference of sex, preparing to read, and learning to distinguish right and wrong, and start developing conscience.

\section{B. The problem of early childhood related developments}

As individuals are growing and developing, early childhood also faces challenges in their development as a result of physical, psychological and social changes. Early childhood physically there are fat, medium and thin. Impaired impulse motion, and motor movements that tend to be lefthanded are also present in early childhood. Psychically early childhood has difficulty in concentrating, likes to lie, easily angry, cries and tend to control his friends. In addition there are early childhood who do not want to be friends, busy with the game itself. Early childhood is also there who do not want to leave their parents at school when they have started to study in early childhood or kindergarten. In addition, social skills and early childhood speaking skills that study in Kindergarten show are still low [8].

Some examples of physical problems and behavioral problems of early childhood as stated above, some lasted for a long time and some are rapidly changing. Some require special handling from experts according to the problems experienced by early childhood. The rapid change from negative behavior to acceptable behavior by the environment will of course make it easier for the child to keep up with the ongoing progress. Such children do not need special treatment to help them. For younger children who are difficult to adjust to the demands of the environment, need to be helped so that they can adjust and accepted the environment.

\section{The Importance of Understanding Developmental Tasks}

Developmental tasks are tasks that appear over a certain age range that, when executed, will help success in following the next developmental task. Conversely, if during the development that is being lived, there are obstacles it can interfere with the achievement of the next developmental tasks. Developmental tasks are skills, achievement levels, and adaptability that are considered important at a certain age for the successful adaptation of a person[9]. There are two kinds of task developmental goals, namely; (1) as an indicator for individuals to know what people expect of them at certain ages, (2) show each individual what they will face and what action is expected of them when it comes to the next level of development [3]. For early childhood, fluency in carrying out developmental tasks certainly can facilitate them through the task of development and education tasks. Adjustment of students who have attended a kindergarten education in the high category, and self-discipline of students who have never attended kindergarten education in the moderate category and there is a significant difference between teachers' perceptions of self-adjustment of students who have attended a kindergarten- and who never attended kindergarten education proved the need for early childhood learning in early childhood [10].

To facilitate early childhood development according to their characteristics, a teacher needs to have an understanding of the progress and tasks that must be carried out accordingly.

\section{Counseling services for early childhood}

Early childhood requires the stimulation of the surrounding environment so that they can develop optimally. Therefore counseling services in early childhood is a process of facilitating the development of learners at PAUD level in order to achieve independence and develop optimally in accordance with the level of development [11]. Counseling services for early childhood direction to; (1) basic services, (2) development services, (3) specialization services, (4) therapeutic services, and (5) expanded services [12]. Basic services are services that lead to the fulfillment of the most basic needs, namely the need for food and drink, fresh air, and health, and the need for socio-emotional relationships for young children. In this case parents, teachers and people close to the early child (significant persons) have the most dominant role in the fulfillment of these basic needs. Development services are services to develop the potential of early childhood in accordance with their stages and developmental tasks. The service of specialization direction is the service aimed at the specialization of early childhood in accordance with the curriculum or program of activities planned in PAUD school or kindergarten. Therapeutic services are services to overcome the problems experienced by early childhood due to disruption of basic services, development services and 
specialization services. While the service is expanded, that is service aimed to people outside self of early child like parents of early child in order to optimize the potential of early childhood.

Implementation of counseling with early childhood differs from counseling services for adult individuals. This difference is more due to early childhood cognitive abilities that tend to think concretely with social contacts are still shy. There are several counseling service options that can be organized to help young children when they need psychological services and educational services from their classroom teachers or school counselors. The counseling services are done by specialists (counselors) and there can be done with the cooperation between class teachers and counselors as well as other related personnel. The format of counseling services is individual format, group format, classical format, field format, and collaborative format [12]. Individual format is the implementation of individual counseling services to service targets. The group format is the implementation of the service to a set of service goals according to the specified criteria. The classical format is the execution of counseling services to classes that require services. The format of the field is the implementation of counseling services with a larger number of targets (many) and can also be in the open field. While the collaborative format is the implementation of counseling services by including the related elements for the optimization of services to the targeted individuals / target groups of services. In its implementation it is necessary to observe the characteristics of early childhood (who will be given services) and experts as the service provider. Individual format counseling services may be undertaken if early childhood requires individualized services from experts (appointed school counselors) for experiencing very personal issues. Implementation can involve parents of early childhood because early childhood still has many limitations in conveying the problems experienced. For children concerning social relationships such as not daring to join the group, do not want to play together can be assisted with group counseling services group. So also with children who tend to interfere with his friends in play, like to rob a game of friends and master the arena game in the school can be assisted with classical counseling service counseling. In addition, it can also be done by involving the child's parents and class teachers using collaborative format counseling services. That is, the selection of the format of counseling services should be tailored to the stage of development and characteristics of children and problems experienced by young children.

Selection of counseling services for early childhood is associated with the mission of counseling services for learners, namely the mission of education, development mission and mission of poverty [12]. The mission of education, the service that facilitates the development of learners through the establishment of effective normative behavior and intelligent character in daily life and the future through the educational efforts that are being undertaken. The mission of development is to facilitate the development of the potential and competence of students with intelligent character in the environment of educational, family and community units. While the mission of eradication is to facilitate the eradication of their problems refers to the effective and intelligent life of everyday life.

There are many options to help young children who have problems. The aid can be directed to help with physical problems, as well as to help with psychological and social problems. Early childhood physical, psychological and social assistance can be pursued by the involvement of parents, schools and communities. Between the school and the family work together to help young children with problems. For parents helping their children grow and develop in line with the developmental task of adults when they have children aged 2.5 to 6 years [13]. This is in line with the implementation of the principle of integration in guidance and counseling services. Integrity and even then can be continued by involving the community in accordance with the issues that need to get attention.

Anyone who cares for early childhood, it is necessary to provide assistance in the form of psycho-paedagogis service or psychological services and educational services. With psychological services and educational services it is possible for children to be able to welcome a better future. In this case, a classroom teacher in early childhood education is responsible for an active and creative learning process because the classroom teacher is the teacher who has the full duty, responsibility, authority and rights in the learning process of all subjects in a particular class in kindergarten / RA / TKLB and SD / MI / SDLB and the equivalent formal education unit, excluding physical and health subject teachers and religious teachers [14].

In addition, classroom teachers help young children overcome the problems they experience so as to facilitate the achievement of educational goals as stated in the formulation of education, namely education is a conscious and planned effort to create an atmosphere of learning and learning process so that learners are actively developing their potential to have religious spiritual strength, self-control, personality, intelligence, noble character, as well as the necessary skills of himself, society, nation and state.

Efforts to educate children naturally done as early as possible through guidance toward habituation so that children grow and develop as intellectually intelligent, emotional, social and spiritual. This is where the need for education services for growth and development of early childhood, because more than $80 \%$ of Indonesian children have not received early childhood education services [2] while early childhood years now, for the next 15 or 20 years they have started to enter the world of work and married (married) who are ready also to give birth to the next child early age.

The above study shows the importance of caring for children at an early age. Therefore, counseling services as one component in education need to be implemented in PAUD schools because the assistance effort for learners in school is an integral part in addition to administration and supervision as well as education and teaching in overall education implementation [11]. This is supported by the results of 
research that the problem of social development of children or patterns of social behavior of children can be overcome through the guidance provided by teachers in accordance with the stage of child development [15].

\section{CONCLUSION}

Early childhood is the age group that needs to be considered physically, psychologically and socially. At an early age there is a change of development that affects further developments. In those days, early childhood needs to get psychological services and educational services from adults, at school and at home. For classroom teachers, they need to position themselves as educators who can facilitate the growth and development of early childhood by understanding the early childhood developmental characteristic, early child development tasks, early childhood problems and psychological services and education services for early childhood so as to help early childhood to realize optimal development. If the classroom teacher does not have the ability to provide psychological services and educational services for early childhood at school, it is necessary to collaborate with counselors as guidance and counseling professionals.

\section{References}

[1] P. R. Indonesia, "Undang-undang Republik Indonesia nomor 20 tahun 2003 tentang sistem pendidikan nasional," 2003.

[2] E. Syaodih and M. Agustin, "Bimbingan Konseling untuk Anak Usia Dini," 2014.

[3] E. B. Hurlock, Instructor's Manual to Accompany “ Developmental Psychology, a Life-span Approach.” McGraw-Hill, 1980.

[4] M. Handayani, "EFEKTIVITAS PERMAINAN TANGRAM TERHADAP PENGENALAN BENTUKGEOMETRI ANAK DI
TAMAN KANAK-KANAK LILLAH TABING PADANGKECAMATAN KOTO TANGAH," J. PESONA PAUD, vol. 11, no. 1, 2015.

[5] Eky Nozzi, "Pentingnya Pendidikan Anak Usia Dini," 2017.

[6] "Early Childhood Developmental Tasks," 2017.

[7] E. A. Prayitno and E. Amti, "Dasar-Dasar Bimbingan dan Konseling,” Jakarta: Rineka Cipta, 2004.

[8] Y. Siska, "Application of Role Playing Methods in Improving Social Skills and Early Childhood Speaking Skills," Univ. Pendidik. Indones., 2011.

[9] Kartini Kartono, Complete Dictionary of Psychology (Translation). PT Raja Grafindo Persada, 2004.

[10] Rina Suryani, “The Teacher's Perception of Self-Adjustment of Students Who Have Attended Kindergarten Education and Who have Never Attended Kindergarten Education,” Universitas Negeri Padang, 2016.

[11] \& I. H. M. Ramli., Nur Hidayah., Elia Flurentin., Ela Farida Zen., Blasius Boli Lasan., "Learning Resources PLPG Subject /Package of Counseling and Guidance Skills," Minist. Educ. Cult. Dir. Gen. Teach. Educ. Pers., 2017.

[12] ABKIN Panduan umum: Layanan konseling dan bimbingan di unit pendidikan dasar dan menengah (SD / MI / SLB, SMP / MTs / SMPLB, SMA / MA / SMALB dan SMK / MAK). 2013.

[13] M. P. Nichols and R. C. Schwartz, Terapia Familiar-: Conceitos e Métodos. Artmed Editora, 2009.

[14] P. M. P. N. Nomor, "Tahun 2010 tentang Petunjuk Teknis Pelaksanaan Jabatan Fungsional Guru dan Angka Kreditnya," Kementeri. Pendidik. dan Kebud., 35AD.

[15] Satri yenita, "Improvement of Social Development of Children Through Information Services in TK Adzkia 1 Padang," Universitas Negeri Padang, 2013. 